\title{
テザー宇宙ロボットの姿勢制御に関する宇宙実証実験解析
}

能見 公博*1

\section{Space verification experimental analysis for attitude control of a tethered space robot}

\author{
Masahiro NOHMI ${ }^{* 1}$ \\ ${ }^{* 1}$ Kagawa Univ. Dept. of Intelligent Mechanical System Engineering \\ 2217-20 Hayashi-cho, Takamatsu-shi, Kagawa 761-0396, Japan
}

\section{Received 28 November 2013}

\begin{abstract}
This paper describes evaluation analysis for the space verification experiment of a tethered space robot on the sounding rocket "S-520-25." The S-520-25 rocket was launched on August 31, 2010. The tether was extended and kept its tension, and attitude control of the tethered space robot was performed. However, experimental results included non-linear dynamic motion, though the attitude control is designed under assumption of linear motion. Then, the space experimental results have been examined by mechanical dynamics software ADAMS. Non-linear motion can be evaluated qualitatively by simulation, and effectiveness of the attitude control has been confirmed.
\end{abstract}

Key words : Space robot, Motion control, Space engineering, Multibody dynamics, Tether

\section{1. 緒言}

テザー宇宙ロボットは 1995 年に提案した, テザー(ひも)の先端にロボットを連結したシステムである (Nohmi, et al., 2001)．テザー先端ロボットはテザーに繫がれているため緊急回収が容易であり，圥長系を持たない最小機 器構成で小型化できる。ささらに予備然料も必要なく, テザー張力を利用した移動, 姿勢制御により燃料が節約で き，小型化へと繋がる。ロボットの軌道上作業を考えると，作業対象があるために，とくに微小重力環境では接 触・衝突の危険性が高い. 小型化は，その被害を最小限に抑えることができる。テザーは軽量・収納性のよさか ら宇宙利用が期待され，古くから研究されている．宇宙実証実験としては，Gemini-Agena プログラム（Lang and Nolting, 1967)，米・伊の共同プロジェクトである Tethered Satellite System Project (Dobrowolny and Melchioni, 1993) が実施されている.一方で，宇宙ロボットの実証実験として，ドイツ航空宇宙研究所による船内ロボット ROTEX

（Hirzinger, et al. 1993），技術試験衛星 VII 型（Oda, 1999）があげられる．テザー宇宙ロボットは，柔軟性かつ非 線形性を持つテザーおよび空間浮遊型ロボット両者の特徴を持ち，これらの既存技術を活用するとともに新規技 術も必要となる.テザーおよびロボットは，宇宙空間においてダイナミックな動作が伴う。空間的な挙動解析は 地上実験では困難であり，また宇宙実証は高コストとなる，とくに，テザーおよび自律ロボットを融合したテザ 一宇宙ロボットは，挑戦的ミッションとなるため，従来手法による宇宙実験では，長期間の十分な地上検証・評 価が求められ，開発コストも高くなる。このような理由から，これらの分野における宇宙実証実験例は少ない. そこで低コストによる宇宙実験を実施していくことを目的とし，香川大学ではテザー宇宙ロボットの宇宙実証実 験を目的とし，実宇宙機の自主開発を進めている.

2009 年 1 月 23 日, 種子島宇宙センターから H-IIA ロケットにより, 香川衛星 STARS (Space Tethered Autonomous Robotic Satellite) を打ち上げた. STARS は親子衛星（能見他，2010），テザー衛星（能見，2009），ロ

\footnotetext{
No.13-00835 [DOI: 10.1299/transjsme.2014se0282]

*1 正員, 香川大学 (干761-0396 香川県高松市林町 2217-20) (現 静岡大学)

E-mail of corresponding author: nohmi@eng.kagawa-u.ac.jp
} 
ボット衛星（能見，2010）の特徴をもち，テザー伸展機能を持つ親衛星からテザー宇宙ロボットである子衛星を 放出することを主ミッションとした．軌道上実験では，テザー伸展距離が十分でなかったため，テザー宇宙ロボ ットのテザー張力を利用した姿勢制御の実証には至らなかったが, 超小型宇宙ロボットとして, 開発, 打ち上げ, 動作実証したことの技術的意義は大きい.

2010 年 8 月 31 日, 宇宙航空研究開発機構（JAXA）の観測ロケット S-520-25 号機により, TSR (Tethered Space Robot) を鹿児島県内之浦から打ち上げた (JAXA HP, 2011). 観測ロケット S-520 は高度 300km 程度まで飛翔し, 10 分間程度の宇宙実験が可能である. 25 号機では JAXA を中心とした首都大学および静岡大学の導電性テザー 実験（渡部他，2012）（山極他，2012）との相乗り実験として，テザー宇宙ロボットの姿勢制御実験を実施した. 本実験では，テザー先端に取り付けられたロボットの姿勢制御効果について，アームを動作させてテザー張力を 利用することにより外乱を抑制できること，目標姿勢を変更できることを評価検証することを目的とした．ここ で, 観測ロケットは機軸回りに約 $1 \mathrm{~Hz}$ の回転をしながら飛翔寸ること, 線形近似により導出した制御法を用いて いることから，実験における非線形効果の影響を無視することはできない，そこで本論文では，汎用機構解析ソ フトウエア ADAMS を用い, 実験における非線形性を含む複雑な挙動を検証し, 姿勢制御効果を評価することを 目的とする. 2 章では観測ロケット S-520-25 号機の実験概要について説明する. 3 章ではテザー宇宙ロボット実 験について, 汎用機構解析ソフトウエア ADAMS によるモデル化を説明する. 4 章に宇宙実験結果を示し，5章 では宇宙実験結果において発生した予想外の複雑な挙動に焦点をあてたシミュレーション解析により, 宇宙実験 結果の信頼性に裏付けをあたえる.

\section{2. テザー宇宙ロボットの S-520-25 観測ロケット実験}

\section{$2 \cdot 1$ S $-520-25$ 実験機器構成}

宇宙航空研究開発機構（JAXA）の観測ロケット S-520-25 号機は，電離層中における導電性テザー（EDT）の 基礎実験と微小重力環境下におけるテザー宇宙ロボットの姿勢制御実証を目的とし, 2010 年 8 月 31 日 05 時 00 分（日本標準時間）に，内之浦宇宙空間観測所から打ち上げられた．ロケットは正常に飛翔し，発射後 55 秒に開 頭し, EDT の基礎実験後の発射後 285 秒からテザー宇宙ロボットの実験を実施した. ロケットは発射後 283 秒で 最高高度 $309 \mathrm{~km}$ に達し, 全ての観測を終え内之浦南東海上に落下した.
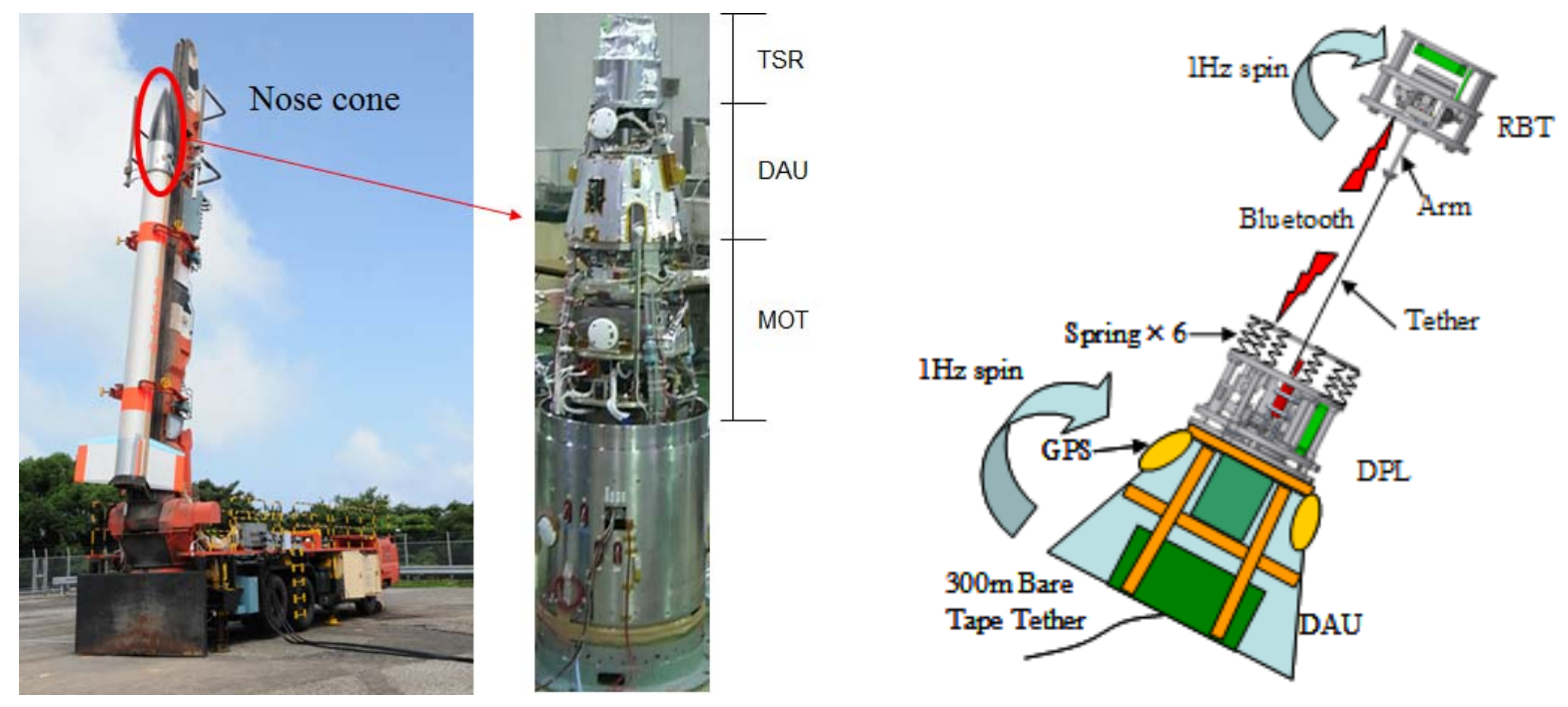

Fig. 1 S-520-25 rocket (left) and TSR experimental device (right) configurations. All experimental devices were mounted in the nose cone, and they consist of MOT (the main EDT experimental device), DAU (the mass for the EDT experiment), and TSR-S (experimental device for a tethered space robot). The right figure shows the experimental device for TSR-S. It consists of DPL (Kevlar tether deployer) and Robot (a tethered space robot), and they are connected by the Kevlar tether. 
S-520-25 号機全体の構成を図 1 に示す，黒色のノーズコーン部分に実験装置は収納され，図中央に示す通り， 下段から MOT (Mother)，DAU (Daughter)，TSR (Tethered Space Robot) で構成される.ロケットは機軸回りに約 $1 \mathrm{~Hz}$ 回転をしながら飛翔する. MOT および DAU は導電性テザー実験装置であり, 発射後 120 秒で分離され両 者を連結する導電性テザーが伸展される．図右に TSR の実験装置構成詳細を示す．TSR は DPL (Deployer) お よび RBT (Robot) から構成され，両者はケブラー（Kevlar）製テザーで連結されている. DPL は DAU に剛結 合されており, テザー伸展装置を搭載している. 発射後 285 秒で DPL とRBT のロウンチロック（打ち上げ固 定）が解除され，290秒で放出バネにより RBT が放出される. DPL-RBT 間は Bluetooth による無線通信が可能 であり，DPL によるテザー長さ情報を受信した RBT はテザー宇宙ロボット姿勢制御を開始する.

\section{$2 \cdot 2$ テザー伸展装置}

図 2 にテザー伸展の実験シーケンスを示す，テザー伸展は，放出バネにより RBT に初速を与えることで開始 される. テザー伸展中はテザー張力制御が行われる. テザー張力制御装置は, テザーリールとエンコーダ IE- 2512 付 DC モータ 2224-006SR（減速機 20/1,3.71:1） [スイス・ミニモータ社製] が, トルク伝達装置パーマトルク HC01-1 [工進精工所製] で連結されているものである. このトルク伝達装置は, 磁力を利用して一定トルクを伝達寸るこ とができ，テザー張力を一定に保つことができる．テザー張力は，地上試験により測定した．テザー伸展時の張 力測定方法は，モータ非駆動状態（位置保持）において，テザーに繋がれた錘を落下させ，加速度を測定し，重 力加速度を $9.8 \mathrm{~m} / \mathrm{s}^{2}$ との加速度の差から算出し, $40 \mathrm{gf}$ の結果を得た. テザー回収時の張力測定方法は, 錘を上皿秤 上に置き，モータ非駆動状態と駆動状態で錘を引き上げる状態の測定值の差から，10gf の結果を得た．この張力 の差は，テザー伸展装置の機構特性（リール慣性，機構摩擦，テザー摩擦）によるものと考えられる.

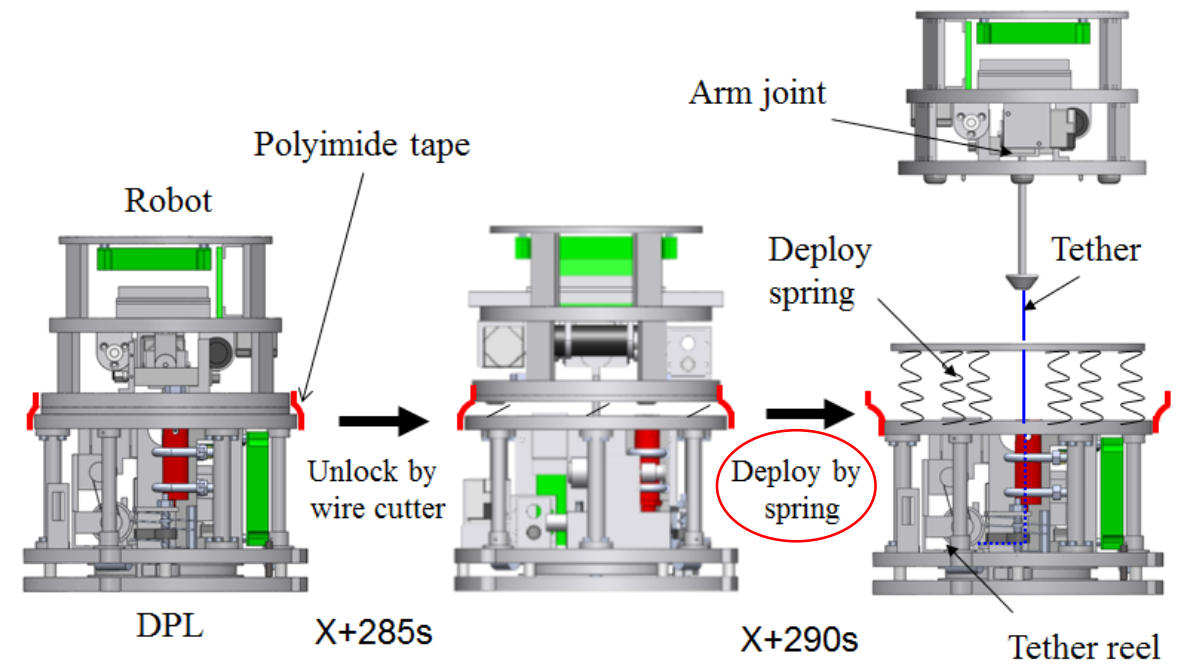

Fig. 2 Tether extension device and its sequence in the S-520-25 experiment. DPL and Robot are fixed by the steel wire (launch lock), and also, deployment springs are compressed by the Nylon wire. The polyimide tape is used for keeping attachment of DPL and RBT from launch lock release time to Nylon wire cutting time.

DPL と RBT の結合状態における外形寸法を以下に示す.

最底部直径 $\phi 200.00 \mathrm{~mm}$, 最上部直径 $\phi 150.00 \mathrm{~mm}$, 高さ $249.60 \mathrm{~mm}$.

ロケット打ち上げ時には, DPL および RBT は鋼線ワイヤにより結合されている (ロウンチロック). また RBT に初速を与える放出バネは，ナイロンテグスにより厓縮状態が維持されている．打ち上げ時刻を X とし，打ち 上げ 285 秒後 $(\mathrm{X}+285)$ にワイヤカッターにより鋼線ワイヤを切断する. この状態で DPL と RBT は分離され ていることとなる. その 5 秒後 $(\mathrm{X}+290)$ にヒータカッターによりナイロンテグスを切断し, 放出バネが伸展し 
テザーに連結された RBT が DPL から放出される. DPL と RBT は Bluetooth による無線通信が行われており, テザー伸展が開始されると, テザーリールによるテザー張力制御が行われるとともに, RBT のアームによる姿勢 制御が開始される.

ロウンチロック解除後から放出までの間, RBT を保持するために図に示すように, ポリイミドテープの接着力 により RBT を DPL に固定する. ポリイミドテープを用いない場合, ロウンチロック解除後は, RBT を保持す るのはテザー張力のみとなるが, DAU の運動を考慮すると十分な保持力はない. RBT が DPL から離れると, 放出バネエネルギーから RBT の運動エネルギーへの変換の損失が大きく, 十分な RBT の初速が得られない. ポリイミドテープの効果は, 図 2 において下方に重力が作用する状態とする地上試験により検証した.

\section{$2 \cdot 3$ テザー宇宙ロボット実験装置}

RBT 外観およびアーム関節機構を図 3 に示す。ここで, ロケットへの搭載は図 2 に示す DPL 側が固定される ため, 図 3 における RBT 外観図の上方向がロケット側となる. RBT の質量及び外形寸法は次の通りである.

質量 $2.488 \mathrm{~kg}$, アーム長さ $100 \mathrm{~mm}$,

底板直径 $\phi 150.00 \mathrm{~mm}$ ，天板直径 $\phi 175.00 \mathrm{~mm}$ ，高さ $201.65 \mathrm{~mm}$ (アームを含む）．

アーム関節機構の動作について説明する．関節には差動歯車機構を用い，二つの DC モータによりアームを軸 方向に垂直な二軸回りに回転させる．ギアは，A，B: DB0.5-2040，C: DB0.5-4020（材質：ベスペル）[小原歯車社 製] で差動歯車を構成し，図右に示寸ように回転入力方向を制御することによりアームを制御できる. 二つのモ ータを駆動することにより，ギア A および B をそれぞれ回転することができる．モータ回転とギア A および B のギア比は $1: 1$ である. ギア C はアームに固定連結されており, ギア $\mathrm{A}$ および $\mathrm{B}$ とギア Cのギア比は $2: 1$ で ある.これより, 図に示寸アーム角度 $\phi_{y, z}$ と入力角度 $\psi_{0,1}$ との関係は次式で表される.

$$
\phi_{y}=\frac{\left(\psi_{0}-\psi_{1}\right)}{4}, \phi_{z}=\frac{\left(\psi_{0}+\psi_{1}\right)}{2}
$$

アーム制御は，電子制御基板に搭載されたマイコン H8/3052 [ルネサステクノロジ社製] により行われる. 制 御周期は $10 \mathrm{~ms}$ とし， $y$ 軸および $z$ 軸に取り付けたジャイロセンサ CRS03-02S [シリコンセンシングシステムジ ヤパン社製] による各軸回りの角速度フィードバックにより, 自作ドライバを用いてエンコーダ IE- 2512 付 DC モータ 2224-006SR（減速機 20/1,134:1） [スイス・ミニモータ社製]を駆動する.
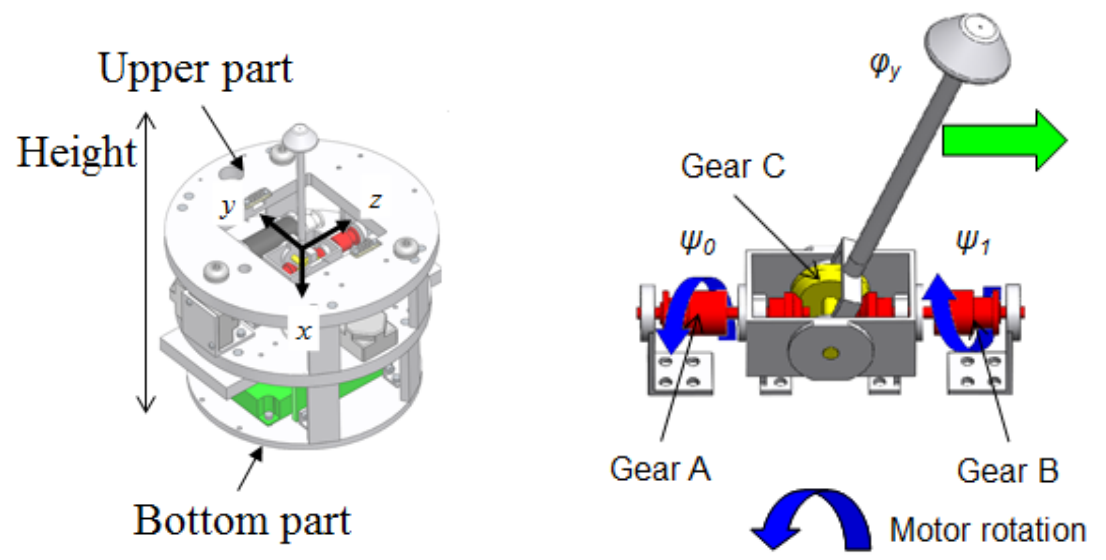

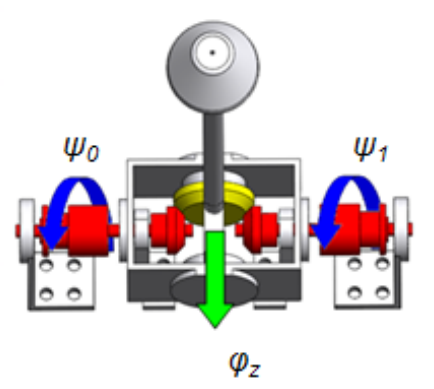

Arm motion

Fig. 3 RBT (left) and arm joint mechanism (right) of the S-520-25 experiment. The arm joint mechanism is a differential gear. The mass and the scale of Robot are: mass $=2.488 \mathrm{~kg}$, radius of the bottom part $=150.00 \mathrm{~mm}$, radius of the top part $=$ $175.00 \mathrm{~mm}$, and the height $=201.65 \mathrm{~mm}$, respectively. Arm link angles $\phi_{y}$ and $\phi_{z}$ can be controlled by the inputs of the two motors $\psi_{0}$ and $\psi_{1}$. 


\section{3. テザー宇宙ロボットのモデル化と制御法}

観測ロケット実験に用いたテザー宇宙ロボットについて, 機構解析ソフトウエア ADAMS で作成した解析モ デルを図 4 に示す. RBT はアームとベースから構成され，アームとベースは図 3 に示した機構による二自由度回 転関節で連結している．テザーは質量を無視した直線近似とし，アーム先端と DPL 間に張力が作用する設定に よりモデル化している．慣性座標系 $X Y Z$ に対し，RBT 固定座標系 $x_{b} y_{b} z_{b}$, DPL 固定座標系 $x_{d} y_{d} z_{d}$, およびテザ 一座標系 $x_{t} y_{t} z_{t}$ を定義する. RBT 固定座標系は原点を RBT 質量中心位置とし, $y_{b}$ 軸および $z_{b}$ 軸は図 3 に示したア 一ム関節の $y$ 軸および $z$ 軸に一致させる. RBT 固定座標系とテザー座標系の姿勢に関する関係は，オイラー角を 用いて次のように定義する.

$$
\left[\begin{array}{l}
x_{b} \\
y_{b} \\
z_{b}
\end{array}\right]=\left[\begin{array}{ccc}
1 & 0 & 0 \\
0 & \cos \theta_{x} & \sin \theta_{x} \\
0 & -\sin \theta_{x} & \cos \theta_{x}
\end{array}\right]\left[\begin{array}{ccc}
\cos \theta_{y} & 0 & -\sin \theta_{y} \\
0 & 1 & 0 \\
\sin \theta_{y} & 0 & \cos \theta_{y}
\end{array}\right]\left[\begin{array}{ccc}
\cos \theta_{z} & \sin \theta_{z} & 0 \\
-\sin \theta_{z} & \cos \theta_{z} & 0 \\
0 & 0 & 1
\end{array}\right]\left[\begin{array}{l}
x_{t} \\
y_{t} \\
z_{t}
\end{array}\right]
$$

RBT 質量中心に対するアーム関節中心位置をベクトル $\boldsymbol{r}$, アーム関節中心に対するアーム先端位置をベクトル $\boldsymbol{l}$, テザー張力ベクトルを $\boldsymbol{n}$ とすると, RBT に作用する回転力 $\boldsymbol{\tau}$ は以下の式で表される.

$$
\tau=(r+l) \times n
$$

ここで $\boldsymbol{r}$ と $x_{b}$ 軸の向きが平行とすると, RBT 固定座標系上において各べクトルは次のように表される.

$$
\mathbf{r}=\left[\begin{array}{c}
-r_{x} \\
0 \\
0
\end{array}\right], \mathbf{l}=-l\left[\begin{array}{c}
\cos \phi_{y} \cos \phi_{z} \\
\cos \phi_{y} \sin \phi_{z} \\
-\sin \phi_{y}
\end{array}\right], \mathbf{n}=-n\left[\begin{array}{c}
\cos \theta_{y} \cos \theta_{z} \\
\cos \theta_{z} \sin \theta_{y} \sin \theta_{x}-\sin \theta_{z} \cos \theta_{x} \\
\cos \theta_{z} \sin \theta_{y} \cos \theta_{x}+\sin \theta_{z} \sin \theta_{x}
\end{array}\right]
$$

ただし, $\|\boldsymbol{l}\|=l,\|\boldsymbol{n}\|=n$ とする.

テザー張力の作用線が RBT の質量中心を通る場合, テザー張力による回転力は発生せず, 回転運動の平衡状態 となる. 平衡状態以外では，テザー張力は平衡状態への復元力を発生させる. すなわち， $x_{t}$ 軸上にアーム先端お よび RBT 質量中心が位置する状態が安定となることから（能見，2005），この状態を姿勢制御目標とする制御 を用いる.ここでは，その制御方法について説明する．目標状態からの変位量は小さいものと仮定し， $\theta_{x, y, z}, \phi_{y, z}$ は 微小であると考えると, $\sin \theta_{x, y, z}=\theta_{x, y, z}, \sin \phi_{y, z}=\phi_{y, z}$, および $\cos \theta_{x, y, z}=\cos \phi_{y, z}=1$ と近似できる. これより, 式 (3) は 以下の通り表される.

$$
\boldsymbol{\tau}=-n\left[\begin{array}{c}
0 \\
\left(r_{x}+l\right) \theta_{y} \\
\left(r_{x}+l\right) \theta_{z}
\end{array}\right]+n l\left[\begin{array}{c}
\theta_{y} \phi_{z}-\theta_{z} \phi_{y} \\
-\phi_{y} \\
-\phi_{z}
\end{array}\right]
$$

式 (5) の $y_{b}$ 軸および $z_{b}$ 軸成分において, 第一項はロボット姿勢が変化することによる回転力, 第二項はアーム 動作による回転力を表している（能見，2005）. 第一項が復元力となることから, 以下に示すアーム制御式によ り第二項を減衰力とすることができる.

$$
\left[\begin{array}{l}
\phi_{y} \\
\phi_{z}
\end{array}\right]=k_{d}\left[\begin{array}{l}
\omega_{y} \\
\omega_{z}
\end{array}\right]+\left[\begin{array}{l}
\phi_{y b} \\
\phi_{z b}
\end{array}\right]
$$


ここで， $k_{d}$ は制御ゲインである。また $\omega_{y}$ および $\omega_{z}$ は RBT の角速度， $\phi_{y b}$ および $\phi_{z b}$ は目標姿勢を決定する アーム姿勢を表し，添え字により $y_{b}$ 軸および $z_{b}$ 軸を示す. 式 (6) を式 (5) に代入することにより，ア一ム制御 を考慮した回転力は以下の通り表される.

$$
\boldsymbol{\tau}=n l\left[\begin{array}{c}
0 \\
-\phi_{y b} \\
-\phi_{z b}
\end{array}\right]+n\left(r_{x}+l\right)\left[\begin{array}{c}
0 \\
-\theta_{y} \\
-\theta_{z}
\end{array}\right]+n l\left[\begin{array}{c}
\theta_{y} \phi_{z}-\theta_{z} \phi_{y} \\
-k_{d} \omega_{y} \\
-k_{d} \omega_{z}
\end{array}\right]
$$

式 (6) から分かるように，アーム姿勢を操作することにより $y_{b}$ 軸および $z_{b}$ 軸回りの回転力を制御できる. す なわちテザー宇宙ロボットは, アーム先端のテザ一連結位置をロボットの質量中心に対して操作することにより, テザー張力により発生する回転力を制御できる.この制御可能な軸， $y_{b}$ 軸および $z_{b}$ 軸を「制御軸」と呼ぶことと する. 制御軸ではない $x_{b}$ 軸回りの回転力は制御できないとともに, 式 (7) から制御軸回りの回転が影響するこ とがわかる.さらに $\phi_{y b}$ および $\phi_{z b}$ により, 制御軸回りの姿勢変更を行うことできる. $\phi_{y b}, \phi_{z b} \neq 0$ の場合を「ア 一ムがオフセットを持つ」と呼ぶこととする.この状態では, テザー張力の作用線が RBT の質量中心を通る平衡 状態において, $\boldsymbol{r}$ と $\boldsymbol{l}$ は平行とはならない.

前述の通り RBT の目標姿勢は， $x_{t}$ 軸上（テザー張力の作用線上）にアーム先端および質量中心が位置する状 態である. これより，アームがオフセットを持たない場合は $x_{t}$ 軸と $x_{b}$ 軸が一致するため $\omega_{x} \neq 0$ の時でも $\omega_{y}$ $=\omega_{z}=0$ となる状態が存在する. しかしアームがオフセットを持つ場合は， $\omega_{x} \neq 0$ の時 $\omega_{y}=\omega_{z}=0$ となる状態は存 在せず, $\omega_{y} \neq 0$ または $\omega_{z} \neq 0$, もしくは $\omega_{y} \neq 0$ かつ $\omega_{z} \neq 0$ となる.
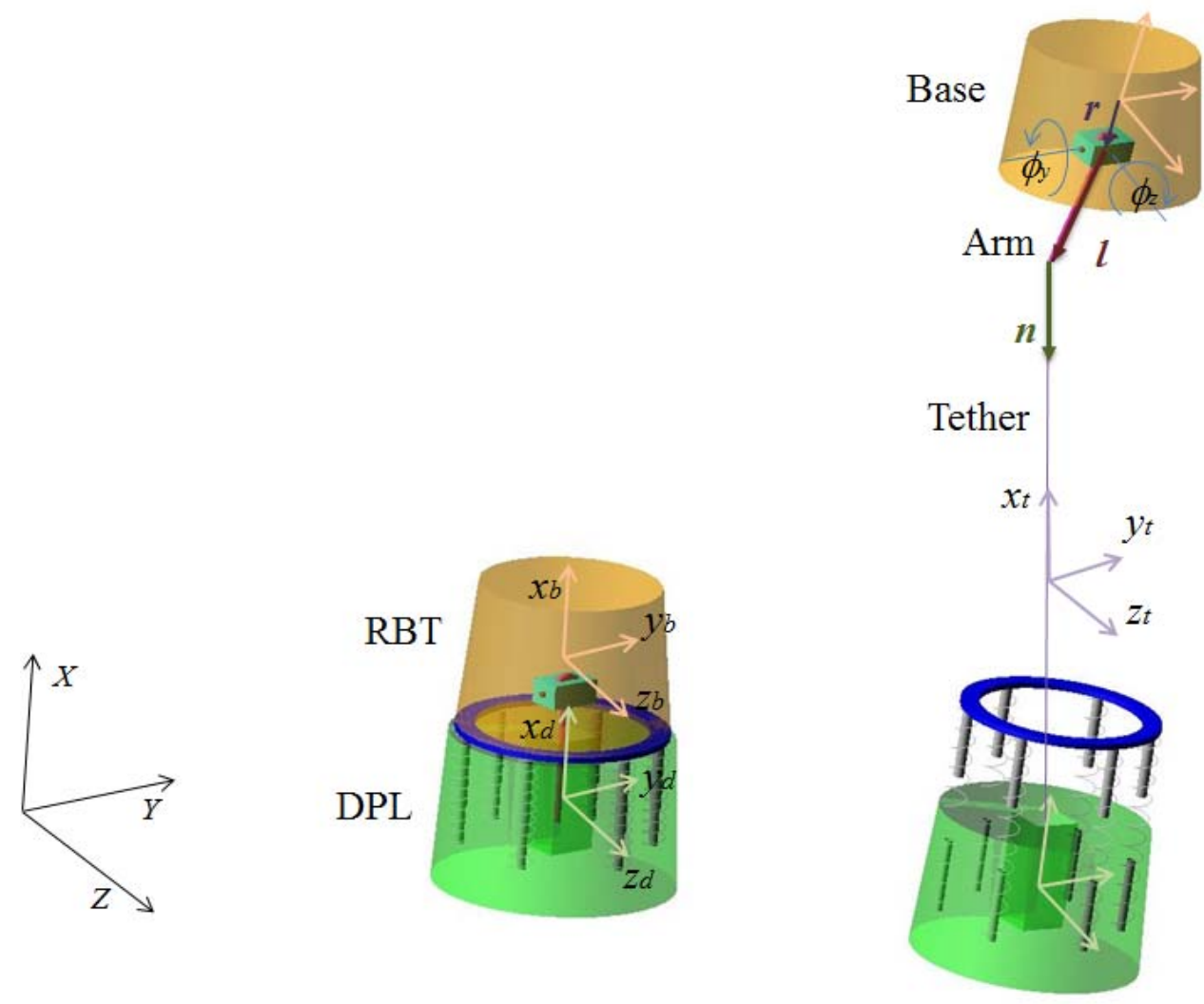

Fig. 4 Analytical model of TSR-S on mechanical dynamics software ADAMS. The origin of the DPL fixed frame is fixed to the inertial frame, and its attitude is restricted based on the experimental data. The position of the RBT mass centre is geometrically determined by the experimental data of tether length and arm link angles. Here, note that tether length should not be restricted because the restriction determines tether tension. 


\section{4. テザ一宇宙ロボットの宇宙実験結果}

\section{$4 \cdot 1$ テザー伸展結果}

図 5 にテザー伸展結果を示す.上段はテザーリールのエンコーダから得られたテザ一長さを示し，下段はその 差分からテザー伸展速度を算出した結果を示す。主要な時間を点線で示し, (a) は鋼線ワイヤ切断を実施した X+285 秒の時点 (Launch lock release), (b) はナイロンテグス切断のためのヒータカッター加熱を実施した X+290 秒の時点 (Tether deployment start), (c) X+315 秒から (d) X+345 秒はリールモータが駆動している時間 (Motor actuation) を示し，この区間以外ではリールモータは停止している.

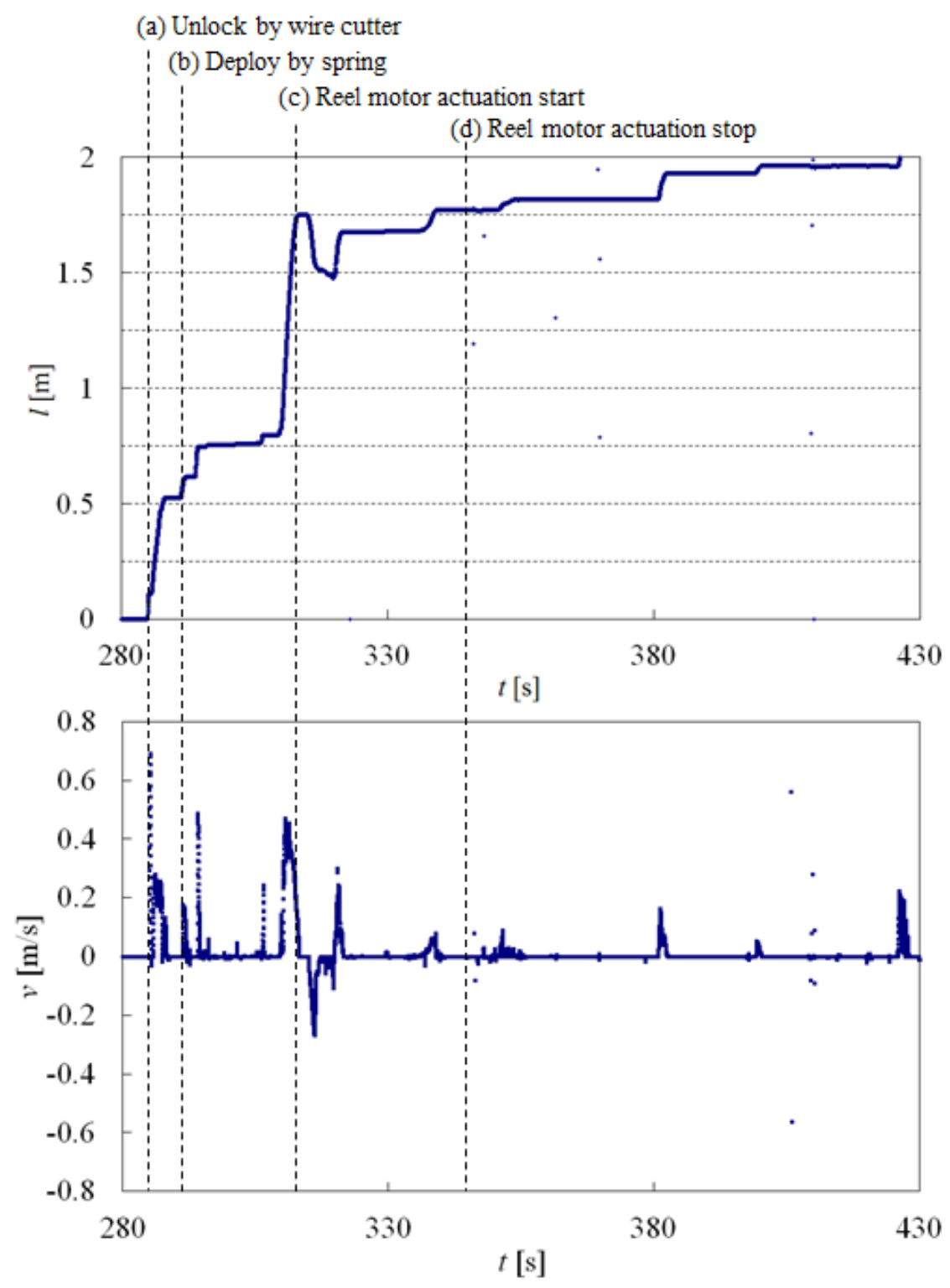

Fig. 5 Experimental result of tether length (upper) and tether extension velocity (below). The launch lock was released at (a), and the tether is extended by springs at (b). But, it is noted that the tether was extended for only about $0.2 \mathrm{~m}$ just after (b). However, it is also noted that the tether was extended continuously. The reason is that DAU translated away largely from RBT. As a result, tether tension was kept by the DAU translation motion, although the initial velocity for tether extension was not enough. 
上段のテザー長さの結果から，(a) と (b) の間にテザーが $0.5 \mathrm{~m}$ 程度伸展されていることがわかる.これは放 出バネの伸展長以上の值であり, (b) において十分な放出バネ力を得たテザー伸展ができなかったことを表して いる. 結果として, (b) 直後の放出バネ力による伸展量は $0.2 \mathrm{~m}$ 程度である.この原因は, DPL を取り付けた DAU の運動が予測以上に大きく, DPL と RBT を保持するポリイミドテープが剥れたためと考えられる. しかしなが ら, 図に示すようにテザ一伸展は (b) 以降も行われている. これは DAU の並進運動が RBT から離れる方向に 大きいためであり, その運動は DAU の運動解析においても確認されている. (c) X+315 秒から (d) X+345 秒ま でのリールモータが駆動している区間はテザーを回収するシーケンスであるが，テザー長さは (c) 直後に $0.2 \mathrm{~m}$ 程度減少しているのみで, その後は増加している。これは DAU の並進運動（渡部他, 2012）に対しテザ一回収 の張力が小さかったことを表している. これらの解析結果から, RBT 放出によるテザー伸展は十分ではなかった が，DAU の並進運動が大きいことにより，RBT にテザー張力が作用する状態を維持できたことがわかる.

テザー張力に関しては, 下段に示寸テザー伸展速度から事前の地上試験結果を参考に推定できる. 正の速度が 出ている箇所はテザー張力 $40 \mathrm{gf}$ で伸展されており, 負の速度が出ている箇所は $10 \mathrm{gf}$ で回収されていると考える ことができる. 速度が $0 \mathrm{~m} / \mathrm{s}$ の場合, リールモータが回転していない箇所では $40 \mathrm{gf}$ 以下, 回転している箇所で は 10 40 gf の張力が作用していると考えることができる.

\section{$4 \cdot 2$ 姿勢制御実験}

観測ロケット実験では, 式 (6) における制御ゲインを $k_{d}=1$ とした. また $\phi_{y b}$ および $\phi_{z b}$ は, ジャイロセン サのオフセットを補正する目的で実験開始直前における平均值を用いることとした結果, $\phi_{y b}=5.23 \mathrm{deg}$ および $\phi_{z b}$ $=50.23 \mathrm{deg}$ となった. これは 3 章で説明した「アームがオフセットを持つ」状態であり，オフセット補正量を大 きく上回っている，その原因は, DAU の運動が予想以上であったためである.

図 6 に姿勢制御実験結果について, RBT の姿勢角速度 $\omega_{x}$ および $\omega_{y}, \omega_{z}$ の時刻歴を示す. $\omega_{x}$ は $x_{b}$ 軸回りの角 速度である，ここでは，実験におけるジャイロセンサのノイズが大きいため，積分による角度表示は困難である ため, 角速度データによる解析を行っている.ここでは次章で論じるシミュレーション結果も示しており, 右肩 添え字により $e$ : 宇宙実験結果, $s$ : シミュレーション結果を表し, さらにメおよびけは後述するシミュレーショ ンから得られる目標角速度を表している. また, 右下添え字は RBT 固定座標系 $x_{b} y_{b} z_{b}$ の各軸成分を示寸. $t_{0}$ は RBT 放出時刻, $t_{s}$ は姿勢制御開始時刻を示寸. 観測ロケットは打ち上げ直後に機軸回りに $1 \mathrm{~Hz}$ の回転を行っているが, 導電性テザー実験により切り離された DAU の回転運動は減衰して $300 \mathrm{deg} / \mathrm{s}$ 程度となっていることが $\omega_{x}^{e}$ の結 果からわかる.

本実験はテザー宇宙ロボットの姿勢制御効果の検証を目的としており, 制御目的は $\theta_{y}$ および $\theta_{z}$ を目標姿勢

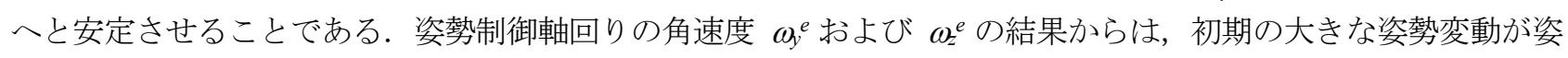
勢制御開始後に抑制されていることから, 制御効果が認められると言える. しかしながら, 角速度変化の振動成 分の中心はゼロでない.この理由は,「アームがオフセットを持つ」状態において, $x_{t}$ 軸回りに回転しているため と考えられる. また制御式 (6) から, このような振動成分が発生寸ることも考えにくい. さらに振動成分の中心 が時間の経過とともにゼロに近づく傾向がみられる.これは $\omega_{x}^{e}$ が変化していることが原因であると考えられる. なお， $\omega_{x}^{e}$ の変化は式 (7) の $x_{b}$ 軸に表される効果であると考えることができる. これらの現象は予測していなか ったものであり, テザー宇宙ロボット実験結果として複雑な挙動となっている. そこで姿勢制御効果の信頼性を 裏付けるために, シミュレーションにより複雑な挙動を解析することとする.

\section{5. シミュレーション解析}

\section{$5 \cdot 1$ 宇宙実験結果の評価検証}

ここでは, 機構解析ソフトウエア ADAMS によって観測ロケット実験の複雑な挙動を再現し, テザー宇宙ロ ボットの姿勢制御効果の信頼性に裏付けをあたえる.

まずシミュレーション方法について述べる. 宇宙実験データとしては, DPL および RBT の角速度, テザー長 さ,アーム姿勢が得られており, RBT および DPL の位置, およびテザー張力は計測していない. 得られた実験 

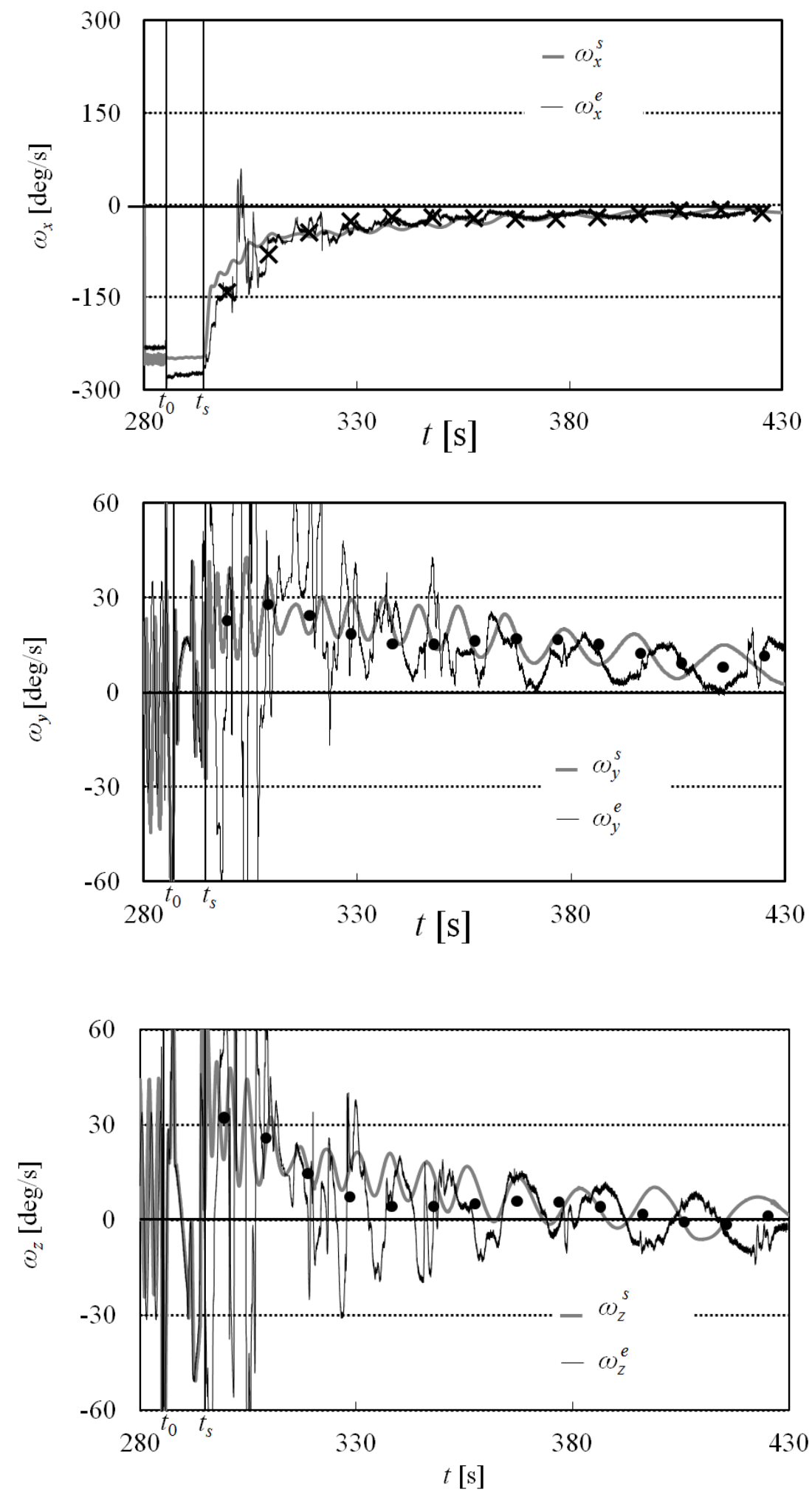

Fig. 6 Experimental and simulation results of angular velocity of TSR. Superscript $e$ shows experimental result, and also $s$ shows simulation result. $t_{s}$ denotes the time when the attitude control was started. It is noted from the $\omega_{y}$ and $\omega_{z}$ results that the large angular velocity at the initial phase was supressed, and that centre values of angular velocity vibration were not equal to be zero, and decreased toward zero. These characteristics are qualitatively same in experimental and simulation results. 
データを，次に説明する通りにシミュレーションに適用する．実験装置において DPL は DAU に固定されてお り, DAU の質量が大きいことから DAU の運動が支配的となる. そこで DPL 固定座標系の原点は固定し, 姿 勢は DPL の角速度（角速度センサー值）を入力する. RBT の並進運動は，テザー長さ（テザーリールのエンコ 一ダ值）とアーム姿勢（アーム関節のエンコーダ值）から幾何学的に RBT 質量中心位置を求め, DPL 固定座標 系と RBT 固定座標系の原点距離を拘束する.ここで, 本解析では回転運動に焦点をあてており, 実験結果から 推定される並進運動量が，回転運動に及ぼす影響は少ないことを考慮している．また，テザー長さ（DPL のテザ 一伸展位置と RBT のアーム先端位置の距離）を直接的に入力寸ることは，テザー張力を表現できなくなること から避けている.そして姿勢初期条件を宇宙実験に一致させるため, RBT が放出され姿勢制御が開始される $t_{s} ま$ では RBT の角速度（角速度センサー值）を入力する. 以上の条件においてシミュレーションを実施し, 結果と して得られた RBT の姿勢角速度について宇宙実験結果と比較する.

ここでシミュレーションパラメータについて説明する. RBT の慣性モーメントは設計值を用い, $I_{x}=7881.76, I_{y}$ $=7387.44, I_{z}=6589.94 \mathrm{kgmm}^{2}$ とした. RBT の質量, アーム長さ, アーム関節中心位置は 2.3 節に記載した值を用 いている．ただし質量に関しては，前述の通りテザー長さと機体姿勢およびアーム角度から質量中心位置を算出 し拘束しているため, 結果的には動力学に影響を与えない. テザー張力は連続性を考慮して地上測定結果の平均 值 $n=30 \mathrm{gf}$ を用いる. ここで実験におけるテザ一張力は $10 \mathrm{gf} \sim 40 \mathrm{gf}$ であることから，各時刻における定量的な 挙動を評価することはできないが，姿勢制御効果を定性的に評価することを目的としている．アーム目標角は宇 宙実験結果と同じ $\phi_{y b}=-5.23 \mathrm{deg}, \phi_{s b}=-50.23 \mathrm{deg}$ ，制御ゲインは宇宙実験における制御法と同じ $k_{d}=1$ とする.

シミュレーション結果を, 前章の観測ロケット実験結果を示寸図 6 に, 右肩添え字 $s$ により示す. これらの結 果を比較すると, 時間とともに振動数が低くなること, 振動の中心がゼロに近付いていくことが, 定性的に同じ 傾向を示している，これより，観測ロケット実験において取得したデータの信頼性を確認できるとともに，テザ 一宇宙ロボット実験装置のモデル化ができたと言える.

\section{$5 \cdot 2$ 目標姿勢と機軸回り角速度の関係}

4.2 節に述べているように，観測ロケット実験において見られた複雑な挙動は，「アームがオフセットを持つ」 こと，および観測ロケットの機軸回りの回転に起因する $\omega_{x}^{e}$ が原因と推定している．そこで，これらの影響がな い場合の挙動をシミュレーションにより調べ， $\omega_{x}^{e}$ の影響を明らかにする.

図 7 にアームがオフセットを持たない場合 $\phi_{y b}=\phi_{z b}=0$ (図中に $\phi_{b}=0$ と表記), 機軸回りの回転がない場合 $\omega_{x}^{s}$ $=0$ (図中に $\omega_{x}=0$ と表記）について，5.1 節の観測ロケット実験と同じ条件の結果（図中に $\phi_{b}=\alpha$ と表記） と

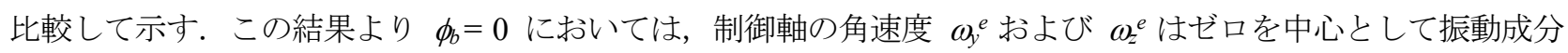
を持つ. すなわち, 振動成分の中心がゼロとならない原因は「アームがオフセットを持つ」ことであると言える.

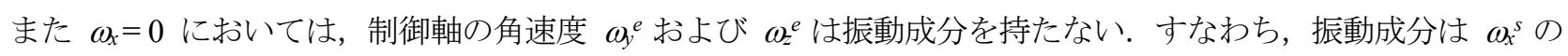
影響であると言える.

さらに，「振動成分の中心が時間の経過とともにゼロに近づく傾向」について調べるため， $\omega_{x}^{s}$ を維持して十分 に時間が経過し安定状態となるシミュレーション解析を行う. その結果について, 安定状態における $\omega_{x}^{s}$ の值 $\omega_{x}^{d}$ に対する $\omega_{y}^{d}$ および $\omega_{z}^{d}$ をプロットしたグラフを図 8 に示す.この結果から, $\omega_{y}^{d}$ および $\omega_{z}^{d}$ の值は $\omega_{x}^{d}$ の值に

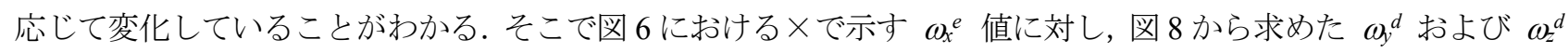
を図 6 に○で示寸.この結果から， $\omega_{y}^{e}$ および $\omega_{z}^{e}$ は安定状態における目標值を中心に振動していると言える.

\section{6. 結 言}

本論文では, テザー宇宙ロボットの観測ロケットによる宇宙実験を実施し, 機構解析ソフトウエア ADAMS を 用いたシミュレーション解析により宇宙実験の挙動を再現し, 実験における姿勢変動が妥当であることを示し, 宇宙実験結果に見られる姿勢制御効果の信頼性に裏付けをあたえた. 宇宙実験では, 予測していなかった現象で ある「アームがオフセットを持つ」こと，テザー宇宙ロボットによる姿勢制御ができない軸回りの回転運動が変 化することにより, テザー宇宙ロボットは複雑な挙動を示した. シミュレーション解析では, これらの挙動を再 現するとともに複雑な挙動のメカニズムを明らかにした. 

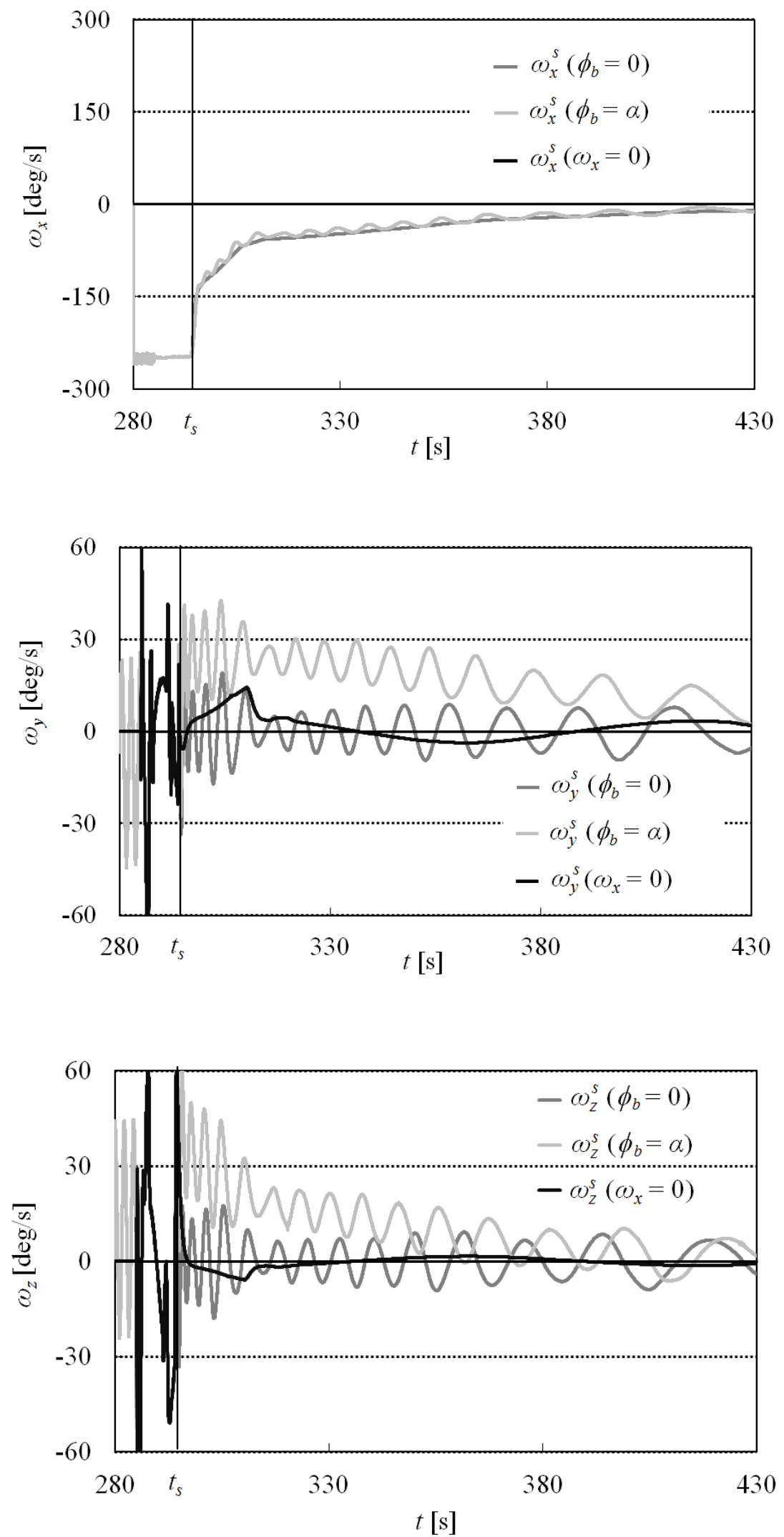

Fig. 7 Influence of arm offset and longitudinal rotation on angular velocity. It is noted that the centre values of angular velocities in the control axes vibrates around zero in case of $\phi_{b}=0$ and $\omega_{x}=0$. Then, it is considered that angular velocity vibrations in the control axes are caused by arm offset and longitudinal rotation. 


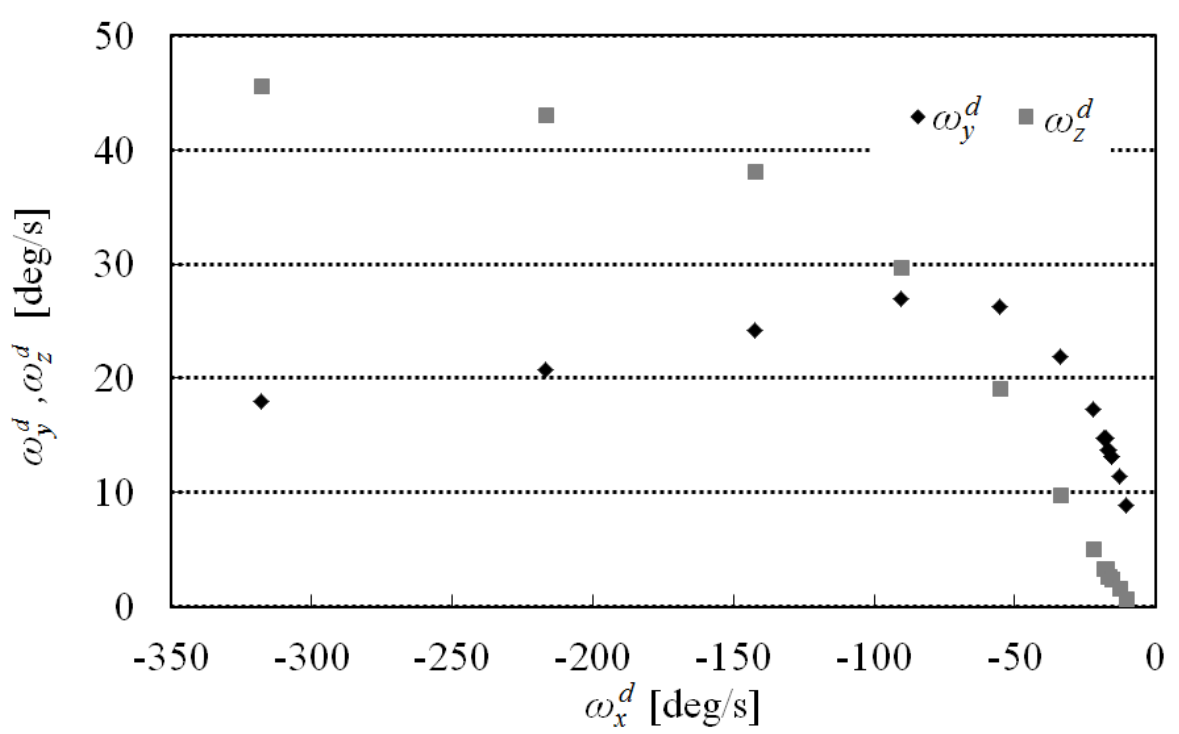

Fig. 8 Angular velocity in equilibrium with arm offset under longitudinal rotation. It can be said that angular velocities in the control axes is determined by angular velocity in the longitudinal axis at the desired condition.

テザー宇宙ロボットの姿勢制御は，アーム操作によりテザー張力による回転力を制御する. このため，テザー 張力（作用線）方向回りの回転運動は，積極的に制御することができない. このテザ一張力方向回りの回転運動 は，「アームがオフセットを持つ」場合の目標姿勢において，制御を行う姿勢軸に角速度を与えることとなり，角 速度フィードバックを行う姿勢制御に影響を及ぼす。さらにテザー張力方向回りの回転運動は, 制御を行う姿勢 軸の回転運動に振動を発生させる.

これらの挙動メカニズムはシミュレーション解析により明らかにした。そして観測ロケット実験において，ロ ケットの機軸回転に起因して発生したテザー張力方向回りの回転運動により，姿勢制御を行う軸回りの運動は振 動成分を持つこと, 振動成分の中心值はテザ一張力方向回りの回転運動の変化に伴って変化すること，さらにア 一ム動作によりテザー張力方向回りの回転運動が変化することがわかった.

以上から，宇宙実験において発生した挙動は理論的に説明することができ，テザー先端に取り付けられたロボ ットの姿勢制御効果について，アームを動作させてテザ一張力を利用することにより，外乱を抑制できているこ と，目標姿勢を変更できることが実証されたと言える.

なお, 本研究は観測ロケット S-520-25 号機によるものであり, 宇宙航空開発研究機構に多大なる支援を受けて いる.ここに感謝の意を表す.

\section{文献}

Dobrowolny, M. and Melchioni, E., Electrodynamic aspects of the first tethered satellite mission, journal of gophysical research, Vol. 98, No. A8(1993), p. 13761.

Hirzinger, G., Brunner, B., Dietrich, J. and Heindl, J., Sensor-based space robotics - ROTEX and its telerobotics features, IEEE transaction on robotics and automation, Vol. 9, No. 5 (1993), pp. 649-663.

JAXA ホームページ，〈http://www.jaxa.jp/press/2010/08/20100831_s520_25_j.html>，（参照日 2011 年 9 月 27 日）.

Lang, D. D. and Nolting, R. R., Operations with tethered space vehicles, gemini summary cnference, Houston, Texas, NASA SP-138 (1967), pp. 55-66.

能見公博, 超小型ロボット衛星の開発と軌道上動作実証, 日本機械学会論文集 C 編, Vol. 76, No. 770 (2010), pp. 2515-2521

能見公博, 山本健志, 糸瀬理, 斎藤隼, 超小型親子衛星 KUKAI のロケット分離機構, 日本機械学会論文集 C 編, 
Vol. 76, No. 765 (2010), pp. 1036-1042.

能見公博, 香川衛星 KUKAI の超小型テザー伸展システム軌道上実験, 日本機械学会論文集 C 編, Vol. 75, No. 760 (2009), pp. 3144-3151.

能見公博，テザー宇宙ロボットの姿勢制御に関する微小重力実験，日本航空宇宙学会論文集，Vol. 53，No. 617 (2005), pp. 281-287.

Nohmi, M., Nenchev, D. N. and Uchiyama, M., Tethered robot casting using a spacecraft mounted manipulator, AIAA journal of guidance, control, and dynamics, Vol. 24, No. 4 (2001), pp. 827-833.

Oda, M., Space robot experiments on NASDA's ETS-VII satellite - Preliminary overview of the experiment results-, proceedings of the 1999 IEEE international conference on robotics and automation, Detroit, MI, (1999), pp.1390-1395.

渡部武夫，藤井裕矩，佐原宏典，海老沼拓史，小島広久，S520-25 号機観測ロケット実験におけるべア導電テー プテザー展開実験，航空宇宙技術，Vol. 11 (2012)，pp. 1-6.

山極芳樹，高木暁生，吉村尚倫，松井信，田中孝治，阿部玩美，佐原宏典，藤井裕矩，観測口ケットによる導電 ベアテザーの作動と荷電粒子収集理論検証実験，航空宇宙技術，Vol. 11 (2012)，pp. 7-14.

\section{References}

Dobrowolny, M. and Melchioni, E., Electrodynamic aspects of the first tethered satellite mission, journal of gophysical research, Vol. 98, No. A8(1993), p. 13761.

Hirzinger, G., Brunner, B., Dietrich, J. and Heindl, J., Sensor-based space robotics - ROTEX and its telerobotics features, IEEE transaction on robotics and automation, Vol. 9, No. 5 (1993), pp. 649-663.

JAXA home page, available from <http:/www.jaxa.jp/press/2010/08/20100831_s520_25_j.html>, (accessed on 27 September, 2011) (in Japanese).

Lang, D. D. and Nolting, R. R., Operations with tethered space vehicles, gemini summary cnference, Houston, Texas, NASA SP-138 (1967), pp. 55-66.

Nohmi, M., Development and orbital performance verification of a robotic pico satellite, transactions of the japan society of mechanical engineers, series C, Vol.76, No.770 (2010), pp.2515-2521 (in Japanese).

Nohmi, M., Yamamoto, T, Itose, O. and Saitou, J., Rocket separation mechanism for pico mother and daughter satellite KUKAI, transactions of the japan society of mechanical engineers, series C, Vol.76, No.765 (2010), pp.1036-1042 (in Japanese).

Nohmi, M., Orbital experiment of tether deployment nano system of kagawa satellite KUKAI, transactions of the japan society of mechanical engineers, series C, Vol.75, No.770 (2009), pp.3144-3151 (in Japanese).

Nohmi, M., Microgravity experiment for attitude control of a tethered space robot, transactions of the japan society for aeronautical and space sciences, Vol. 53, No. 617 (2005), pp. 281-287 (in Japanese).

Nohmi, M., Nenchev, D. N. and Uchiyama, M., Tethered robot casting using a spacecraft mounted manipulator, AIAA journal of guidance, control, and dynamics, Vol. 24, No. 4 (2001), pp. 827-833.

Oda, M., Space robot experiments on NASDA's ETS-VII satellite - Preliminary overview of the experiment results-, proceedings of the 1999 IEEE international conference on robotics and automation, Detroit, MI, (1999), pp.1390-1395.

Watanabe, T., Fujii, H., Sahara, H., Ebinuma, T. and Kojima, H., Deployment of bare electro-dynamic tape tether on sounding rocket S520-25, aerospace technology Japan, Vol. 11 (2012), pp. 1-6 (in Japanese).

Yamagiwa, Y., Takagi, A., Yoshimura, N., Matsui, M., Tanaka, K., Abe, T., Sahara H. and Fujii, H., Verification experiment of bare electrodynamic tether operation and charged particle collection theory by using sounding rocket, aerospace technology Japan, Vol. 11 (2012), pp. 7-14 (in Japanese). 